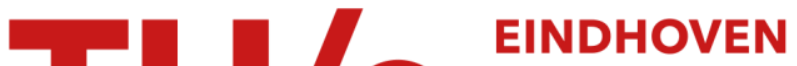 UNIVERSITY OF TECHNOLOGY
}

\section{The magnitude and reproducibility of the electroosmotic flow in silica capillary tubes}

\section{Citation for published version (APA):}

Coufal, P., Stulik, K., Claessens, H. A., \& Cramers, C. A. (1994). The magnitude and reproducibility of the electroosmotic flow in silica capillary tubes. Journal of High Resolution Chromatography, 17(5), 325-334. https://doi.org/10.1002/jhrc.1240170509

DOI:

10.1002/jhrc.1240170509

Document status and date:

Published: 01/01/1994

\section{Document Version:}

Publisher's PDF, also known as Version of Record (includes final page, issue and volume numbers)

\section{Please check the document version of this publication:}

- A submitted manuscript is the version of the article upon submission and before peer-review. There can be important differences between the submitted version and the official published version of record. People interested in the research are advised to contact the author for the final version of the publication, or visit the $\mathrm{DOI}$ to the publisher's website.

- The final author version and the galley proof are versions of the publication after peer review.

- The final published version features the final layout of the paper including the volume, issue and page numbers.

Link to publication

\section{General rights}

Copyright and moral rights for the publications made accessible in the public portal are retained by the authors and/or other copyright owners and it is a condition of accessing publications that users recognise and abide by the legal requirements associated with these rights.

- Users may download and print one copy of any publication from the public portal for the purpose of private study or research.

- You may not further distribute the material or use it for any profit-making activity or commercial gain

- You may freely distribute the URL identifying the publication in the public portal.

If the publication is distributed under the terms of Article 25fa of the Dutch Copyright Act, indicated by the "Taverne" license above, please follow below link for the End User Agreement:

www.tue.nl/taverne

Take down policy

If you believe that this document breaches copyright please contact us at:

openaccess@tue.nl

providing details and we will investigate your claim. 


\title{
The Magnitude and Reproducibility of the Electroosmotic Flow in Silica Capillary Tubes
}

\author{
Pavel Coufal and Karel Štulík \\ Department of Analytical Chemistry, Faculty of Science, Charles University, Albertov 2030, 12843 Prague 2, Czech Republic
}

Henk A. Claessens* and Carel A. Cramers

Laboratory of Instrumental Analysis, Eindhoven University of Technology, P.O. Box 513, 5600 MB Eindhoven, The Netherlands

\section{Key Words:}

\author{
Capillary electrophoresis \\ Repeatability of electroosmotic flow \\ Silica capillary tubes \\ Column pretreatment
}

\begin{abstract}
Summary
The influence of a number of factors, such as the nature of the buffer, the presence of additives therein, the manufacturing conditions, and the pretreatment of the capillary, on the magnitude and repeatability of the electroosmotic flow (EOF) in silica capillary tubes has been investigated. It was established that the nature of the buffer plays the most significant role in respect of the stability and magnitude of EOF, whereas the conditions used for manufacture and pretreatment of the tubing are less important. The EOF obtained using buffers consisting of tris(hydroxymethyl)aminomethane and ethylenediamine was more repeatable than that obtained using pure phosphate buffers. Buffer additives such as sodium dodecylsulfate, 1-butanol, sodium salts of 1-pentanesulfonic acid and 1-heptanesulfonic acid, altered the magnitude of the EOF only, not its repeatability.
\end{abstract}

\section{Introduction}

Separation techniques applying a high voltage drop across a fused silica capillary are employed in a wide, and still increasing area, for analysis of charged and neutral substances. The application of a potential across a bare silica capillary tube filled with electrolyte results in the well known electrokinetic phenomenon, the electroosmotic flow (EOF) of the electrolyte through the capillary [1]. The double-layer theory treating the electrical and flow parameters of this electrokinetic transport was developed by Helmholtz et al. [2]. It is difficult to control EOF through fused silica capillaries satisfactorily; $\mathrm{EOF}$ is very often unstable over a period of time.

The electroosmotic mobility, and consequently the magnitude of the EOF can be influenced by a number of factors [3-6], including the dielectric constant and viscosity of the electrolyte, and the zeta potential at the shear plane in the electrical double-layer. According to von Smoluchowski's equation [7]:

$v_{e o}=-\frac{\varepsilon_{0} \times \varepsilon_{\mathrm{I}} \times \zeta}{\eta}=-m_{\mathrm{eo}} \times E$

where $v_{e o}$ is the electroosmotic velocity, $\varepsilon_{0}$ is the permittivity of a vacuum, $\varepsilon_{\mathrm{r}}$ is the relative permittivity of the electrolyte solution, $\zeta$ is the zeta potential, $E$ is the applied electric field strength, $\eta$ is the viscosity of the electrolyte solution, and $m_{\mathrm{eo}}$ is the electroosmotic mobility.

The $\mathrm{pH}$ of the running buffer is one of the main experimental variables affecting EOF. A change in the $\mathrm{pH}$ of the buffer solution may modify both the surface charge of the capillary wall and the equilibrium constant for adsorption of cations on the silica surface, resulting in a change in the zeta potential $[3,4,8-13,22,34]$.

Because the buffer composition may also influence the dielectric constant and viscosity of the buffer solution, and consequently the zeta potential, the influence of the buffer anions and cations on the EOF has been studied [3,14-18]. The buffer concentration alters the ionic strength of the solution and thus affects the zeta potential and EOF $[3,14,18]$. Organic solvents present in the running buffer also modify the EOF $[3,4,14,19]$, and additives in the running buffer, e.g. surfactants $[9,10,20,24-29,33,36]$, nitrogen-containing compounds [21-23], and some other substances [30], may also influence the magnitude and stability of the EOF.

When a silica capillary tube is treated with an acidic or alkaline solution before use, the surface charge on the capillary wall may decrease or increase and a porous gel layer at the silica - solution interface may be formed or removed. Because these changes of the silica surface alter the zeta potential $[4,8,34]$, it is obvious that the repeatability and magnitude of EOF is affected by the type and frequency of pretreatment and rinsing of capillary tubes [33]. The inner surface of a silica capillary tube can also be coated with compounds of low or high molecular weight, either for deactivation or to control EOF $[3,10,11,13,31,35]$.

The EOF may also be controlled by application of an external electric field to the capillary [32].

Because experimental data on the magnitude and repeatability of EOF in capillaries are sometimes contradictory, and there is a lack of systematic studies, we have studied the influence of a number of factors, such as the nature of the buffer, the presence of additives therein, capillary pretreatment methods, and manufacturing conditions, on the magnitude and repeatability of EOF in bare silica capillary tubing.

\section{Experimental}

\subsection{Instrumentation}

A Prince (Lauerlabs, Emmen, The Netherlands) version 1 programmable injector for capillary electrophoresis was used for repeatable electrokinetic injection of the samples; the injector's integral oven was used to thermostat the capillary columns at $30^{\circ} \mathrm{C}$. Open, polyimide-clad fused silica capillary tubes $55 \mathrm{~cm} \times 50 \mu \mathrm{m}$ i.d. ( $370 \mu \mathrm{m}$ o.d.), were supplied by Siemens (Müheim, Germany), Chrompack (Middelburg, The Netherlands), SGE (Melbourne, Australia), and J\&W Scientific (Folsom, USA) and used as the columns. The columns were provided with an optical window $40 \mathrm{~cm}$ from the inlet. An on-column UV absorbance detector (Unicam Analytical Systems, Cambridge, UK) was used at a wavelength of $200 \mathrm{~nm}$. A dC power supply ( $\pm 35 \mathrm{kV}$; HCN 140-35000, FUG Electronik GmbH, Germany), controlled by the programmable injector, was used to generate an electric field across the columns. Platinum wires were 


\section{Table 1}

The buffers used.

\begin{tabular}{|c|c|c|c|}
\hline Abbreviation & $\mathrm{pH}$ & Component $^{\mathrm{a})}$ & Concentration \\
\hline PHOS & 6.8 & $\begin{array}{l}\text { sodium dihydrogen phosphate dihydrate, extra pure } \\
\text { di-sodium hydrogen phosphate dehydrate, p.a. }\end{array}$ & $\begin{array}{l}10 \mathrm{mM} \\
10 \mathrm{mM}\end{array}$ \\
\hline TRIS & 8.2 & $\begin{array}{l}\text { tris(hydroxymethyl)aminomethane, p.a. } \\
\text { acetic acid, p.a. }\end{array}$ & $\begin{array}{l}20 \mathrm{mM} \\
\text { pH adjustment }\end{array}$ \\
\hline PHOSAM $^{*}$ & 7.4 & $\begin{array}{l}\text { sodium dihydrogen phosphate dihydrate, extra pure } \\
\text { ethylenediamine, for synthesis }\end{array}$ & $\begin{array}{l}20 \mathrm{mM} \\
10 \mathrm{mM}\end{array}$ \\
\hline PHOSAM $^{*}+$ SDS & 8.5 & $\begin{array}{l}\text { di-sodium hydrogen phosphate dihydrate, p.a. } \\
\text { ethylenediamine, for synthesis } \\
\text { SDS, (Aldrich Chemical Company, Inc., USA) }\end{array}$ & $\begin{array}{l}20 \mathrm{mM} \\
10 \mathrm{mM} \\
50 \mathrm{mM}\end{array}$ \\
\hline
\end{tabular}

a) All chemicals except SDS were supplied by Merck (Darmstadt, Germany).

used to connect the injection unit to the positive electrode and the buffer reservoir on the detector side to the grounded electrode. A Tulip R AT Compact 3 computer ('s-Hertogenbosch, The Netherlands) with a home-made Multilab-TS interface and the Caesar program (B-Wise Software, Geleen, The Netherlands) was employed for data acquisition and calculation.

\subsection{Chemicals}

The buffers used in the experiments are summarized in Table 1 Dodecyl sulfate, sodium salt (Aldrich, USA; $50 \mathrm{mM}$ ) was added to some buffer solutions. Formamide p.a. (Janssen Chimica, Belgium; $5 \mathrm{mM}$ ) in the corresponding buffers, served as the EOF marker. Other chemicals used were sodium hydroxide, p.a., and nitric acid, p.a. (Merck), 1-butanol, p.a. (Riedel-de-Haën, Germany), 1-pentanesulfonic acid, sodium salt, HPLC grade, and 1-heptanesulfonic acid, sodium salt, HPLC grade (FSA, UK). The water used for the preparation of the solutions was purified with a Milli-Q Water Purification System (Millipore Corp., USA)

\subsection{Procedures}

Silica capillary tubes were subjected to either alkaline or acidic pretreatment or were not pretreated at all. Alkaline pretreatment was performed by flushing the capillary with $1 \mathrm{M}$ sodium hydroxide solution for $10 \mathrm{~min}$ and then with water for another $10 \mathrm{~min}$ at a pressure drop of 500 mbar. Acidic pretreatment was started by flushing the capillary with $0.1 \mathrm{M}$ nitric acid solution for $30 \mathrm{~min}$ at a pressure drop of 3 bar, after which the capillary was $90 \%$ filled with the nitric acid solution, the capillary ends were sealed by flame heating, and the closed capillary tube was heated for $120 \mathrm{~min}$ at $120^{\circ} \mathrm{C}$. After opening, the tube was washed with water for $30 \mathrm{~min}$ at a pressure drop of 3 bar.

The pretreated or untreated capillary was flushed with the first running buffer solution for $10 \mathrm{~min}$ at a pressure drop of $500 \mathrm{mbar}$ and then the first set of runs from a measurement matrix was started. Before every new run the capillary was washed with the actual running buffer for $2 \mathrm{~min}$ at a pressure drop of $500 \mathrm{mbar}$ (about two volumes of the capillary). A sample was then injected electrokinetically at $5 \mathrm{kV}$ for $0.08 \mathrm{~min}$, and a separation voltage of $15 \mathrm{kV}$ was applied across the capillary until the formamide peak was detected. Each analysis procedure was repeated several times to enable appropriate statistical calculations within a set of runs

To change from one running buffer to another, the capillary was rinsed with the new buffer solution for $10 \mathrm{~min}$ at a pressure drop of 500 mbar before starting a new set of runs. In some instances, the capillary was first washed with water for $10 \mathrm{~min}$, then with the new buffer solution for another $10 \mathrm{~min}$ at a pressure drop of $500 \mathrm{mbar}$. Between some sets of runs the running buffer located in the inlet vial was, moreover, substituted with a new one to examine the effect of this change on $\mathrm{EOF}$.

Ovemight and during weekends buffer solution or water was left inside the capillary tube under study to prevent its drying out.

\section{Results and Discussion}

The electroosmotic mobility $m_{e o}$ was calculated from eq. (2) [8].

$m_{\mathrm{eO}}=\frac{l_{\mathrm{ID}} \times l_{\mathrm{TOT}}}{V t}=\frac{l_{\mathrm{ID}}}{E t}$

where: $I_{D}$ is the distance between the inlet end of the capillary and the detector window, hot is the total length of the capillary, $V$ is the applied voltage, and $t$ is the migration time of the EOF marker.

Fifteen different capillary columns were prepared and subjected to EOF measurements using the various buffers listed in Table 1. The columns investigated are summarized in Table 2. As an example, Figure 1 and Table 3 describe all the sets of analyses within the matrix of measurements performed on column S6. The set numbers and the numbers of analyses within one set in Figure 1 correspond to the numbers in Table 3. Similar matrixes of measurements were performed with the other columns listed in Table 2, and the data were statistically evaluated and compared. The variation of the electroosmotic mobility corresponding to a change in one of the investigated factors, the other conditions being kept constant, was used as a measure of the ability of the individual parameter to influence the electroosmotic mobility. The variations in electroosmotic mobility were expressed as $R S D$ values 
Table 2

The columns used.

\begin{tabular}{lll}
\hline Abbreviation & Manufacturer & Pretreatment \\
\hline S1 & Siemens & Alkaline \\
S2 & Siemens & Alkaline \\
S3 & Siemens & Acidic \\
S4 & Siemens & Acidic \\
S5 & Siemens & Alkaline \\
S6 & Siemens & None \\
S7 & Siemens & Alkaline \\
S8 & Siemens & None \\
S9 & Siemens & None \\
C1 & Chrompack & Alkaline \\
C4 & Chrompack & Acidic \\
E1 & SGE & Alkaline \\
E8 & SGE & None \\
J1 & J\&W & Alkaline \\
J11 & J\&W & None \\
\hline
\end{tabular}

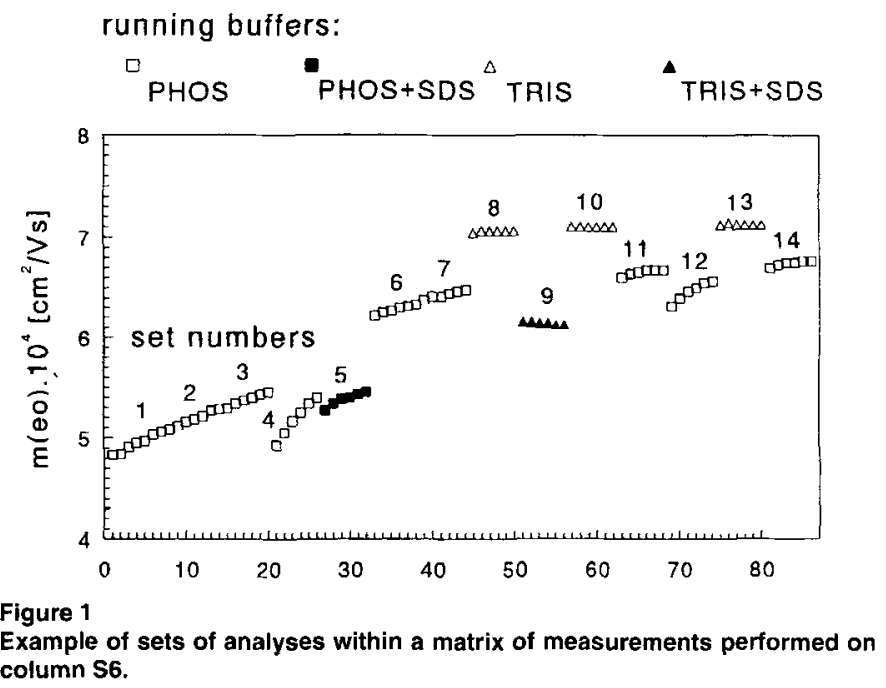

Table 3

Sets of analyses within a matrix of measurements performed on column S6.

\begin{tabular}{|c|c|c|c|c|c|}
\hline $\begin{array}{l}\text { Set } \\
\text { number }\end{array}$ & $\begin{array}{l}\text { Washing } \\
\text { buffera) }\end{array}$ & $\begin{array}{l}\text { Analysis } \\
\text { number }\end{array}$ & $\begin{array}{l}\text { Average } \\
m_{\mathrm{eo}} \times 10^{4} \\
{\left[\mathrm{~cm}^{2} / \mathrm{Vs}\right]}\end{array}$ & $\begin{array}{l}R S D \\
\text { within } \\
\text { a set }\end{array}$ & $\begin{array}{l}\text { Number of } \\
\text { analyses } \\
\text { in the set }\end{array}$ \\
\hline 1 & W. PHOS & $1-8$ & 4.959 & 1.93 & 8 \\
\hline 2 & S. inlet buffer & $9-14$ & 5.202 & 1.24 & 6 \\
\hline 3 & S. injet buffer & $15-20$ & 5.381 & 1.13 & 6 \\
\hline \multirow[t]{2}{*}{4} & PHOS overnight, & & & & \\
\hline & no washing & $21-26$ & 5.188 & 3.40 & 6 \\
\hline 5 & W. PHOS + SDS & $27-32$ & 5.379 & 1.26 & 6 \\
\hline 6 & W. PHOS & $33-38$ & 6.282 & 0.68 & 6 \\
\hline 7 & W. water, PHOS & $39-44$ & 6.436 & 0.59 & 6 \\
\hline 8 & W. water, TRIS & $45-50$ & 7.062 & 0.12 & 6 \\
\hline 9 & W. TRIS + SDS & $51-56$ & 6.142 & 0.23 & 6 \\
\hline 10 & W. TRIS & $57-62$ & 7.106 & 0.00 & 6 \\
\hline 11 & W. water, PHOS & $63-68$ & 6.658 & 0.43 & 6 \\
\hline \multirow[t]{2}{*}{12} & PHOS over weekend & & & & \\
\hline & W. water, PHOS & $69-74$ & 6.468 & 1.50 & 6 \\
\hline 13 & W. water, TRIS & $75-80$ & 7.130 & 0.11 & 6 \\
\hline 14 & W. water, PHOS & $81-86$ & 6.747 & 0.41 & 6 \\
\hline
\end{tabular}

a) W., wash with; S., substitution of

\subsection{Dependence of Variations in Electroosmotic Mobility on Column Pretreatment and Buffer Composition}

The results of statistical treatment of the data are given in Table $\mathbf{4}$, where 'Number of sets' indicates the number of sets of analyses performed under identical conditions. The mean values of the electroosmotic mobility calculated from the average values of the electroosmotic mobilities of the identical sets of analyses are presented in the column headed 'Mean $m_{e o}$ '. The $R S D$ values characterize the variations of the electroosmotic mobility between different sets of analyses performed on a column under specific conditions, i.e. the set-to-set repeatability of the EOF. The last column of Table 4 contains the mean values of the relative standard deviations calculated from the individual sets of analyses. These mean values characterize the variations of the electroosmotic mobility within individual sets of analyses, i.e the analysis-to-analysis repeatability of the $\mathrm{EOF}$
It can be concluded from the data in Table 4 that use of the TRIS buffer resulted in a higher electroosmotic mobility than did use of the PHOS buffer. The best set-to-set repeatability of the electroosmotic mobilities was attained with the PHOSAM and PHOSAM* buffers. The EOF stability was also satisfactory with the TRIS buffer. Poorer EOF repeatability was observed with the PHOS buffer. With PHOS buffers the stability of the electroosmotic mobility was, moreover, also slightly affected by the capillary pretreatment procedure. The EOF repeatabilities within the sets of analyses were better for TRIS, PHOSAM and PHOSAM* buffers than for PHOS buffers.

3.2 Variations of Electroosmotic Mobility Between Different Columns from the Same Manufacturer used under Identical Pretreatment and Buffer Conditions

From the $R S D$ values (calculated from mean electroosmotic mobility values) given in Table 5 it can be concluded that between-column variations are slightly higher than the variation of the electroosmotic 
Table 4

Mean values, relative standard deviations $(R S D)$ and mean $R S D$ values for the electroosmotic mobility.

\begin{tabular}{|c|c|c|c|c|c|c|c|}
\hline Column & Manufacturer & Pretreatment & Buffer & $\begin{array}{l}\text { Number } \\
\text { of sets }\end{array}$ & $\begin{array}{l}\text { Mean } m_{\mathrm{eo}} \\
{\left[10^{-4} \mathrm{~cm}^{2} / \mathrm{Vs}\right]}\end{array}$ & $\begin{array}{l}R S D \\
{[\%]}\end{array}$ & $\begin{array}{l}\text { Mean } R S D \\
{[\%]}\end{array}$ \\
\hline S1 & Siemens & Alkaline & TRIS & 10 & 6.370 & 3.4 & 0.49 \\
\hline $\mathrm{C} 1$ & Chrompack & Alkaline & TRIS & 10 & 6.729 & 3.8 & 0.42 \\
\hline E1 & $\mathrm{SGE}$ & Alkaline & TRIS & 10 & 7.294 & 2.2 & 0.34 \\
\hline $\mathrm{J} 1$ & $\mathrm{~J} \& W$ & Alkaline & TRIS & 10 & 7.378 & 3.9 & 0.60 \\
\hline $\mathrm{S} 2$ & Siemens & Alkaline & TRIS & 7 & 6.671 & 2.9 & 0.40 \\
\hline S3 & Siemens & Acidic & TRIS & 13 & 7.090 & 3.6 & 0.51 \\
\hline $\mathrm{S} 9$ & Siemens & None & TRIS & 9 & 6.621 & 4.2 & 0.45 \\
\hline S8 & Siemens & None & PHOSAM & 9 & 5.676 & 2.6 & 0.54 \\
\hline E8 & SGE & None & PHOSAM & 9 & 5.787 & 2.9 & 0.50 \\
\hline J11 & $\mathrm{J} \& \mathrm{~W}$ & None & PHOSAM $^{*}$ & 9 & 2.926 & 2.4 & 0.62 \\
\hline S2 & Siemens & Alkaline & PHOS & 6 & 6.457 & 7.0 & 0.83 \\
\hline S7 & Siemens & Alkaline & PHOS & 9 & 6.404 & 5.3 & 1.06 \\
\hline S5 & Siemens & Alkaline & PHOS & 14 & 6.789 & 3.7 & 0.47 \\
\hline S4 & Siemens & Acidic & PHOS & 9 & 6.359 & 12.8 & 1.68 \\
\hline $\mathrm{C4}$ & Chrompack & Acidic & PHOS & 9 & 5.801 & 11.1 & 1.50 \\
\hline S6 & Siemens & None & PHOS & 9 & 5.925 & 12.2 & 1.26 \\
\hline S7 & Siemens & Alkaline & TRIS & 3 & 7.271 & 1.2 & 0.19 \\
\hline S4 & Siemens & Acidic & TRIS & 3 & 7.687 & 1.5 & 0.23 \\
\hline $\mathrm{C} 4$ & Chrompack & Acidic & TRIS & 3 & 7.090 & 2.0 & 0.20 \\
\hline S6 & Siemens & None & TRIS & 3 & 7.099 & 0.5 & 0.08 \\
\hline S1 & Siemens & Alkaline & PHOS & 3 & 4.817 & 2.1 & 1.03 \\
\hline $\mathrm{Cl}$ & Chrompack & Alkaline & PHOS & 3 & 5.830 & 2.0 & 0.43 \\
\hline E1 & SGE & Alkaline & PHOS & 3 & 6.599 & 2.7 & 0.45 \\
\hline J1 & $\mathrm{J} \& W$ & Alkaline & PHOS & 3 & 6.636 & 2.6 & 0.91 \\
\hline S3 & Siemens & Acidic & PHOS & 2 & 5.813 & 4.1 & 1.82 \\
\hline S8 & Siemens & None & PHOS & 3 & 6.956 & 0.3 & 0.30 \\
\hline S9 & Siemens & None & PHOS & 3 & 5.781 & 8.8 & 1.37 \\
\hline E8 & SGE & None & PHOS & 3 & 7.086 & 1.8 & 0.18 \\
\hline J11 & $\mathrm{J} \& W$ & None & PHOS & 3 & 6.658 & 2.1 & 0.41 \\
\hline
\end{tabular}

columns:

$+S 1 \quad--\Delta-C 1 \quad-\theta-E 1 \quad \cdots \boxminus \cdots l$

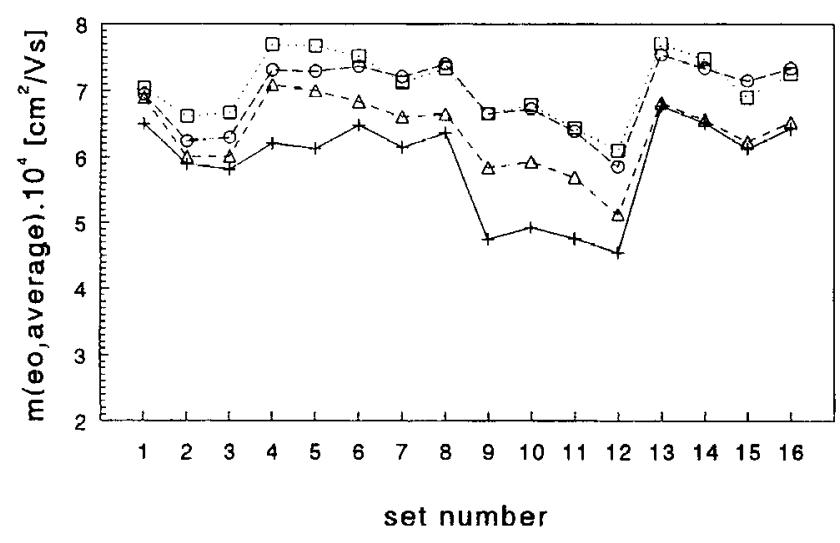

Figure 2

Average values of electroosmotic mobilities for individual sets of analyses within a matrix of measurements performed on columns $\mathrm{S1}, \mathrm{C} 1, \mathrm{E} 1$, and $\mathrm{J} 1$. Sets $1,4,5,6,7,8,13,14,15$, and 16, TRIS buffer; sets 2 and 3 , TRIS buffer + SDS; sets 9, 10 and 11, PHOS buffer; set 12, PHOS buffer + SDS. Sets $1-6$ were measured the first day, sets 7-14 the second day, and sets 15-16 the third day. columns:

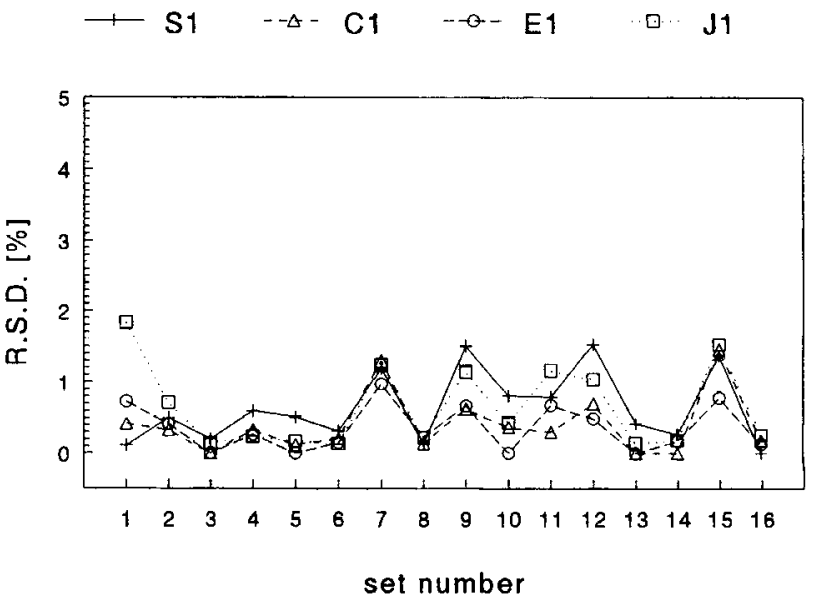

Figure 3

RSD values of the electroosmotic mobilities for individual sets of analyses within a matrix of measurements performed on columns S1, C1, E1, and J1. Sets $1,4,5,6,7,8,13,14,15$, and 16, TRIS buffer; sets 2 and 3 , TRIS buffer + SDS; sets 9,10 , and 11, PHOS buffer; set 12, PHOS buffer + SDS. Sets $1-6$ were measured the first day, sets 7-14 the second day, and sets 15-16 the third day. 
Table 5

Mean values, $R S D$ values, and mean RSD values for the electroosmotic mobility of various columns from the same manufacturer under identical pretreatment and buffer conditions.

\begin{tabular}{|c|c|c|c|c|c|c|c|}
\hline Column & Manufacturer & Pretreatment & Buffer & $\begin{array}{l}\text { Number } \\
\text { of sets }\end{array}$ & $\begin{array}{l}\text { Mean } m_{P O} \\
{\left[10^{-4} \mathrm{~cm}^{2} / \mathrm{Ns}\right]}\end{array}$ & $\begin{array}{l}R S D \\
{[\%]}\end{array}$ & $\begin{array}{l}\text { Mean RSD } \\
{[\%]}\end{array}$ \\
\hline S1 & Siemens & Alkaline & TRIS & 10 & 6.370 & & 0.49 \\
\hline $\mathrm{S} 2$ & Siemens & Alkaline & TRIS & 7 & 6.671 & & 0.40 \\
\hline S3 & Siemens & Alkaline & TRIS & 3 & 7.271 & 6.8 & 0.19 \\
\hline S1 & Siemens & Alkaline & PHOS & 3 & 4.817 & & 1.03 \\
\hline $\mathrm{S} 2$ & Siemens & Alkaline & PHOS & 6 & 6.457 & & 0.83 \\
\hline S7 & Siemens & Alkaline & PHOS & 10 & 6.404 & 15.8 & 1.06 \\
\hline S3 & Siemens & Acidic & TRIS & 13 & 7.090 & & 0.51 \\
\hline S4 & Siemens & Acidic & TRIS & 3 & 7.687 & 5.7 & 0.23 \\
\hline S3 & Siemens & Acidic & PHOS & 2 & 5.813 & & 1.82 \\
\hline S4 & Siemens & Acidic & PHOS & 9 & 6.359 & 6.3 & 1.68 \\
\hline S6 & Siemens & None & TRIS & 3 & 7.099 & & 0.08 \\
\hline S9 & Siemens & None & TRIS & 9 & 6.621 & 4.9 & 0.45 \\
\hline S6 & Siemens & None & PHOS & 9 & 5.925 & & 1.26 \\
\hline S9 & Siemens & None & PHOS & 3 & 5.781 & 1.7 & 1.37 \\
\hline
\end{tabular}

Table 6

Mean values, $R S D$ values, and mean $R S D$ values for the electroosmotic mobility in columns from different manufacturers under identical pretreatment and buffer conditions.

\begin{tabular}{|c|c|c|c|c|c|c|c|}
\hline Column & Manufacturer & Pretreatment & Buffer & $\begin{array}{l}\text { Number } \\
\text { of sets }\end{array}$ & $\begin{array}{l}\text { Mean } m_{\mathrm{eO}} \\
{\left[10^{-4} \mathrm{~cm}^{2} / \mathrm{Vs}\right]}\end{array}$ & $\begin{array}{l}R S D \\
{[\%]}\end{array}$ & $\begin{array}{l}\text { Mean } R S D \\
{[\%]}\end{array}$ \\
\hline S1 & Siemens & Alkaline & TRIS & 10 & 6.370 & & 0.49 \\
\hline C1 & Chrompack & Alkaline & TRIS & 10 & 6.7291 & & 0.42 \\
\hline $\mathrm{J} 1$ & $J \& W$ & Alkaline & TRIS & 10 & 7.378 & & 0.60 \\
\hline E1 & $\mathrm{SGE}$ & Alkaline & TRIS & 10 & 7.294 & 6.9 & 0.34 \\
\hline S1 & Siemens & Alkaline & PHOS & 3 & 4.817 & & 1.03 \\
\hline $\mathrm{C} 1$ & Chrompack & Alkaline & PHOS & 3 & 5.830 & & 0.43 \\
\hline $\mathrm{J} 1$ & $J \& W$ & Alkaline & PHOS & 3 & 6.636 & & 0.91 \\
\hline E1 & SGE & Alkaline & PHOS & 3 & 6.599 & 14.3 & 0.45 \\
\hline S4 & Siemens & Acidic & TRIS & 3 & 7.687 & & 0.23 \\
\hline $\mathrm{C} 4$ & Chrompack & Acidic & TRIS & 3 & 6.756 & 9.1 & 0.20 \\
\hline S4 & Siemens & Acidic & PHOS & 9 & 6.359 & & 1.68 \\
\hline $\mathrm{C} 4$ & Chrompack & Acidic & PHOS & 9 & 5.801 & 6.5 & 1.50 \\
\hline S8 & Siemens & None & PHOSAM & 9 & 5.676 & & 0.54 \\
\hline E8 & SGE & None & PHOSAM & 9 & 5.787 & 1.4 & 0.50 \\
\hline S8 & Siemens & None & PHOS & 3 & 6.956 & & 0.30 \\
\hline E8 & SGE & None & PHOS & 3 & 7.086 & 1.3 & 0.18 \\
\hline
\end{tabular}

mobility over different sets of analyses performed with a single column using a specific buffer (Table 4).

3.3 Variations of Electroosmotic Mobility Between Columns from Different Manufactures used under Identical Pretreatment and Buffer Conditions

The RSD values (calculated from the mean values of the electroosmotic mobility) given in Table 6 are comparable with those in
Tables 4 and 5 . This similarity in the statistical results shows that the differences between columns from different manufacturers are statistically insignificant compared to the differences between different sets of analyses performed with one specific column using a specific buffer and/or between different columns supplied by the same manufacturer. It was also found that the differences between columns from different manufacturers are influenced by the selection of the buffer and the pretreatment procedure. It can be con- 
cluded from Table 6 that for PHOSAM buffers the differences between columns $\mathrm{S} 8$ and $\mathrm{E} 8$, supplied by different manufacturers, are very small. The influence of the buffer on the differences between columns from different manufactures can also be observed in Figures $\mathbf{2}$ and 3, which depict average values and $R S D$ values for the electroosmotic mobilities within individual sets of identical analyses performed on columns S1, C1, E1, and J1 from different manufacturers. It is clear that variations in the average values of the electroosmotic mobilities and in the RSD values is larger for sets 9 , 10, 11, and 12 in which PHOS buffers were used
3.4 Variations of Electroosmotic Mobility Between Columns from the same Manufacturer Subjected to Different Pretreatment Procedures and Used Under the Same Buffer Conditions

These variations (Table 7) are again expressed in terms of the RSD values calculated from the mean values of electroosmotic mobility.

It follows from Tables $5-7$ that differences between electroosmotic mobilities of columns pretreated by different procedures are also statistically insignificant compared with the effects of the other factors investigated. In these experiments it was, however, ob-

Table 7

Mean values, RSD values, and mean RSD values for the electroosmotic mobility in columns from the same manufacturer subjected to different pretreatment procedures and used under the same buffer conditions.

\begin{tabular}{|c|c|c|c|c|c|c|c|}
\hline Column & Manufacturer & Pretreatment & Buffer & $\begin{array}{l}\text { Number } \\
\text { of sets }\end{array}$ & $\begin{array}{l}\text { Mean } m_{\mathrm{e}} \\
{\left[10^{-4} \mathrm{~cm}^{2} / \mathrm{Vs}\right]}\end{array}$ & $\begin{array}{l}R S D \\
{[\%]}\end{array}$ & $\begin{array}{l}\text { Mean RSD } \\
{[\%]}\end{array}$ \\
\hline S6 & Siemens & None & TRIS & 3 & 7.099 & & 0.08 \\
\hline S7 & Siemens & Alkaline & TRIS & 3 & 7.271 & & 0.19 \\
\hline S4 & Siemens & Acidic & TRIS & 3 & 7.687 & 4.1 & 0.23 \\
\hline S6 & Siemens & None & PHOS & 9 & 5.925 & & 1.26 \\
\hline S7 & Siemens & Alkaline & PHOS & 9 & 6.404 & & 1.06 \\
\hline S4 & Siemens & Acidic & PHOS & 9 & 6.359 & 4.2 & 1.68 \\
\hline S9 & Siemens & None & TRIS & 9 & 6.621 & & 0.45 \\
\hline S1 & Siemens & Alkaline & TRIS & 10 & 6.370 & & 0.49 \\
\hline S3 & Siemens & Acidic & TRIS & 13 & 7.090 & 5.5 & 0.51 \\
\hline S9 & Siemens & None & PHOS & 3 & 5.781 & & 1.37 \\
\hline S1 & Siemens & Alkaline & PHOS & 3 & 4.817 & & 1.03 \\
\hline S3 & Siemens & Acidic & PHOS & 2 & 5.813 & 10.3 & 1.82 \\
\hline
\end{tabular}

columns:

$\longrightarrow \mathrm{S} 4 \quad--\Delta-\mathrm{C} 4 \quad-\theta-\mathrm{S} 7 \quad 0 \quad \mathrm{~S} 6$

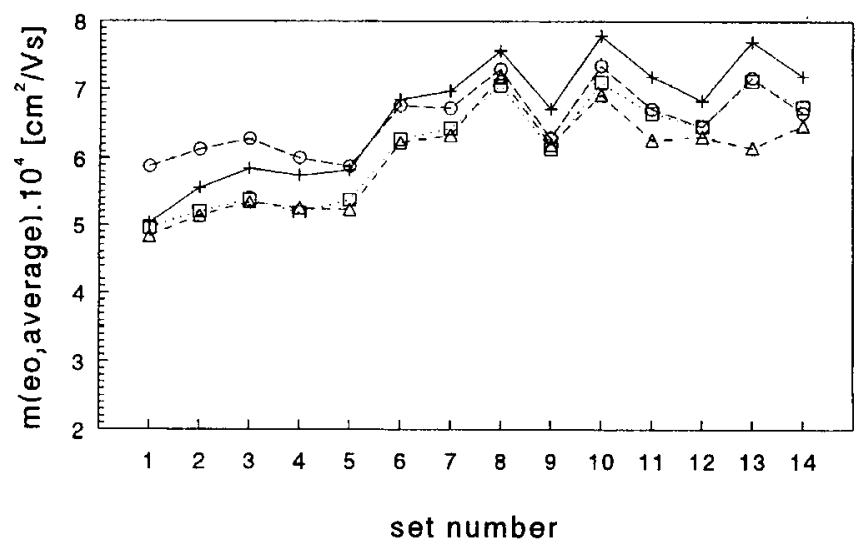

Figure 4

Average values of the electroosmotic mobilities for individual sets of analyses within a matrix of measurements performed on columns $\mathrm{S4}, \mathrm{C4}, \mathrm{S7}$, and $\mathrm{S6}$. Sets 1, 2, 3, 4, 6, 7, 11, 12, and 14, PHOS buffer; set 5, PHOS buffer + SDS; sets 8,10 , and 13, TRIS buffer; set 9, TRIS buffer + SDS. Sets 1-3 were measured the first day, sets 4-11 the second day, and sets 12-14 the third day. columns:

$\begin{array}{lllll}-S 4 & -\Delta-C 4 & -0-S 7 & \square & -S 6\end{array}$

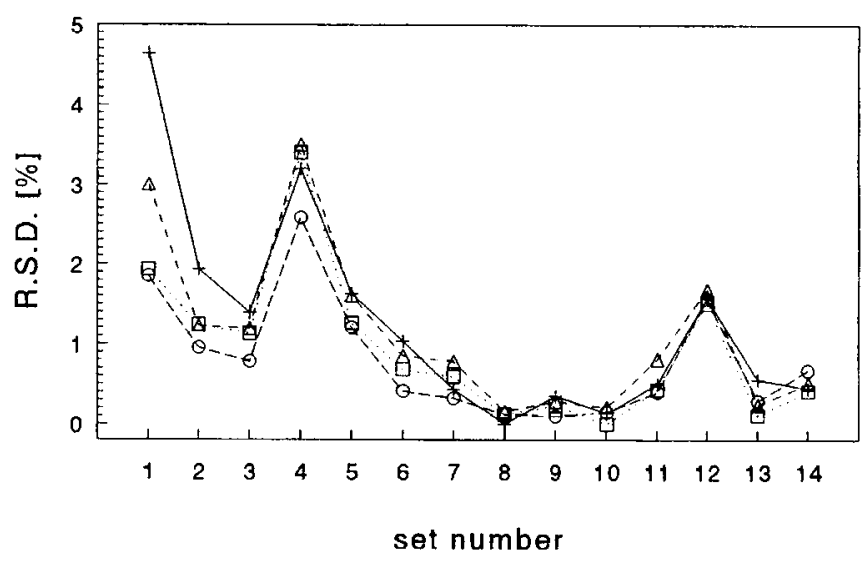

Figure 5

$R S D$ values of the electroosmotic mobilities for individual sets of analyses within a matrix of measurements performed on columns $S 4, C 4,57$, and $S 6$. Sets 1, 2, 3, 4, 6, 7, 11, 12, and 14, PHOS buffer; set 5. PHOS buffer + SDS; sets 8,10 , and 13 , TRIS buffer; set 9 , TRIS buffer + SDS. Sets 1-3 were measured the first day, sets 4-11 the second day, and sets 12-14 the third day. 
Table 8

The 'first - last' RSD values and the 'first' and 'last' $R S D$ values for the electroosmotic mobilities for various pretreatment and buffer conditions.

\begin{tabular}{|c|c|c|c|c|c|c|c|}
\hline Column & Manufacturer & Pretreatment & Buffer & $\begin{array}{l}\text { Number } \\
\text { of sets }\end{array}$ & $\begin{array}{l}R S D \\
{[\%]}\end{array}$ & $\begin{array}{l}\text { RSD first } \\
{[\%]}\end{array}$ & $\begin{array}{l}\text { RSD last } \\
{[\%]}\end{array}$ \\
\hline S1 & Siemens & Alkaline & TRIS & 10 & 0.8 & 0.11 & 0.00 \\
\hline $\mathrm{C} 1$ & Chrompack & Alkaline & TRIS & 10 & 3.9 & 0.42 & 0.18 \\
\hline E1 & $\mathrm{SGE}$ & Alkaline & TRIS & 10 & 3.8 & 0.73 & 0.13 \\
\hline $\mathrm{J} 1$ & $\mathrm{~J} \& W$ & Alkaline & TRIS & 10 & 2.1 & 1.83 & 0.26 \\
\hline S3 & Siemens & Acidic & TRIS & 13 & 5.1 & 0.89 & 1.03 \\
\hline 59 & Siemens & None & TRIS & 9 & 5.8 & 0.65 & 0.12 \\
\hline S8 & Siemens & None & PHOSAM & 9 & 2.3 & 1.04 & 0.01 \\
\hline E8 & SGE & None & PHOSAM & 9 & 2.0 & 1.40 & 0.10 \\
\hline $\mathrm{J} 11$ & $\mathrm{~J} \& W$ & None & PHOSAM ${ }^{*}$ & 9 & 1.3 & 0.63 & 0.33 \\
\hline $\mathrm{S} 2$ & Siemens & Alkaline & PHOS & 5 & 8.9 & 1.40 & 0.97 \\
\hline S7 & Siemens & Alkaline & PHOS & 9 & 8.8 & 1.85 & 0.67 \\
\hline S5 & Siemens & Alkaline & PHOS & 14 & 6.6 & 0.77 & 0.16 \\
\hline S4 & Siemens & Acidic & PHOS & 9 & 25.0 & 4.64 & 0.44 \\
\hline $\mathrm{C} 4$ & Chrompack & Acidic & PHOS & 9 & 20.6 & 3.00 & 0.51 \\
\hline S6 & Siemens & None & PHOS & 9 & 21.6 & 1.93 & 0.41 \\
\hline
\end{tabular}

served that the procedure used for column pretreatment influenced the magnitude and the repeatability of EOF during the first sets of analyses performed on a freshly prepared column. This is illustrated in Figures $\mathbf{4}$ and $\mathbf{5}$ which show the average values of electroosmotic mobility and the corresponding RSD values within the individual sets of analyses performed with columns S4, C4, S7, and S6. The matrixes of measurements are the same as in Figure 1 and Table 3. These differences diminished, however, after a few sets of analyses had been performed.

The buffer used can also strongly modify the influence of column pretreatment on EOF, as is apparent from Table 8, which summarizes the $R S D$ values of the overall average electroosmotic mobilities obtained from the first and last measurements obtained from a set of identical analyses. It can be seen that the PHOS buffer in combination with a column subjected to the acidic or no pretreatment procedure (columns $\mathrm{S} 4, \mathrm{C} 4$, and $\mathrm{S} 6$ ) leads to very poor EOF repeatability during the first set of analyses; in the last sets of analyses, however, EOF stability was comparable with that obtained from the last sets of analyses performed on columns subjected to the alkaline pretreatment (columns S2, S7, and S5). Furthermore, for acidic pretreatment or no pretreatment, and using the TRIS or PHOS buffers, the differences between the electroosmotic mobilities

Table 9

The influence of column pretreatment and the nature of the buffer on the repeatability and magnitude of the electroosmotic mobilities in a freshly prepared column during the first sets of analyses. The statistical results were calculated from the data presented in Figure 6.

\begin{tabular}{|c|c|c|c|c|c|c|c|c|}
\hline \multirow[b]{2}{*}{ Column } & \multirow[b]{2}{*}{ Pretreatment } & \multirow[b]{2}{*}{ Buffer } & \multicolumn{3}{|c|}{ Calculated from analyses: } & \multirow[b]{2}{*}{$\begin{array}{l}15-20 \\
R S D[\%]\end{array}$} & \multirow[b]{2}{*}{$\begin{array}{l}1-20 \\
\text { Mean } m_{\mathrm{eo}}\end{array}$} & \multirow[b]{2}{*}{$\begin{array}{l}1-20 \\
R S D[\%\end{array}$} \\
\hline & & & $\begin{array}{l}1-6 \\
\text { Mean } m_{\mathrm{eo}} \\
{\left[10^{-4} \mathrm{~cm}^{2} / \mathrm{Vs}\right]}\end{array}$ & $\begin{array}{l}15-20 \\
\text { Mean } m_{\mathrm{eO}} \\
{\left[10^{-4} \mathrm{~cm}^{2} / \mathrm{Vs}\right]}\end{array}$ & $\begin{array}{l}1-6 \\
R S D[\%] \\
{\left[10^{-4} \mathrm{~cm}^{2} / \mathrm{Vs}\right]}\end{array}$ & & & \\
\hline S7 & Alkaline & PHOS & 5.837 & 6.282 & 1.53 & 0.78 & 6.075 & 3.14 \\
\hline S4 & Acidic & PHOS & 4.943 & 5.849 & 4.02 & 1.39 & 5.435 & 7.19 \\
\hline S6 & None & PHOS & 4.921 & 5.381 & 1.56 & 1.13 & 5.158 & 3.80 \\
\hline S9 & None & TRIS & 6.513 & 6.589 & 0.59 & 0.00 & 6.557 & 0.57 \\
\hline S8 & None & PHOSAM & 5.748 & 5.784 & 1.02 & 0.12 & 5.785 & 0.74 \\
\hline
\end{tabular}

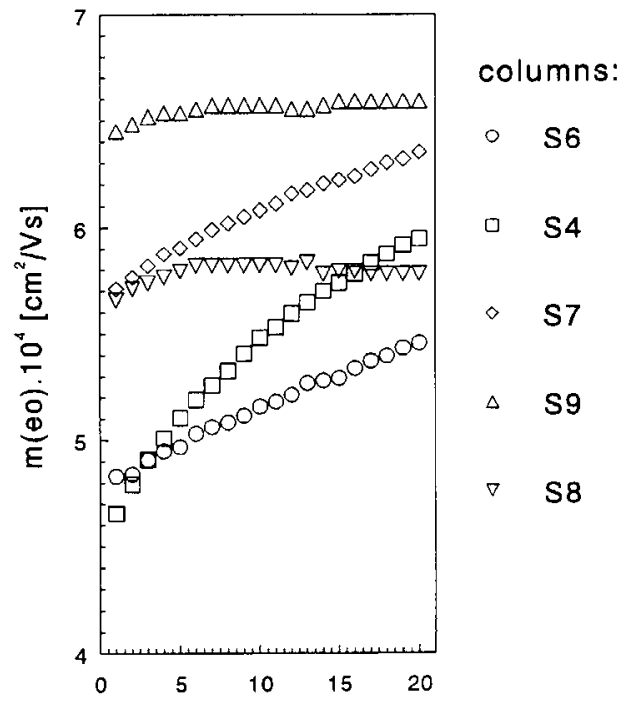

Figure 6

The influence of the column pretreatment and the nature of the buffer on the first sets of analyses. Column description and data evaluation are given in Table 9. stability and magnitude of the EOF in a freshly prepared column during the 
measured during the first and last identical sets of analyses on a single column were larger than the differences obtained after alkaline pretreatment

Figure $\mathbf{6}$ and Table $\mathbf{9}$ show that selection of the correct buffer is of major importance for rapid attainment of a repeatable EOF; the effect of the pretreatment procedure is much smaller. TRIS and PHOSAM buffers, used with columns S9 and S8, yielded a very stable EOF after only five analyses. Experiments with PHOS buffer and columns subjected to different pretreatment (columns S7, S4, and S6) showed, on the other hand, that a satisfactorily stable EOF was not attained even after twenty analyses.

\subsection{The Influence of the Nature of the Buffer on Variations in Elec- troosmotic Mobility}

It was demonstrated above that buffer selection plays a more significant role in respect of the stability and repeatability of EOF than either the manufacturing or pretreatment procedures used. It can be concluded from the results summarized in Table 4 that similar repeatabilities of electroosmotic mobility within the individual sets of analyses can be obtained for TRIS, PHOSAM, and PHOSAM* buffers. The EOF stability was also significantly better than with PHOS buffers. The best set-to-set EOF repeatability was attained for the PHOSAM and PHOSAM* ${ }^{*}$ buffers, whereas that for the PHOS buffer was poorer. The within-set and set-to-set repeatabilities of the electroosmotic mobility with PHOS buffers were also found to depend on the capillary pretreatment procedure.

The influence of the nature of the buffer on $\mathrm{EOF}$ is also demonstrated in Figures $\mathbf{7}$ and $\mathbf{8}$, which give the average values and the $R S D$ values of the electroosmotic mobilities within the individual sets of analyses performed on the untreated columns S6, S9, S8, E8, and J11, applying similar matrixes of measurements as those in Figure 1 and Table 3 . The buffer solutions used in the individual sets of analyses are summarized in Table 10. From Figure 7 it can be concluded that during the first sets of analyses the highest electroosmotic mobility was observed for the TRIS buffer $(\mathrm{pH}=8.2)$ and

columns:

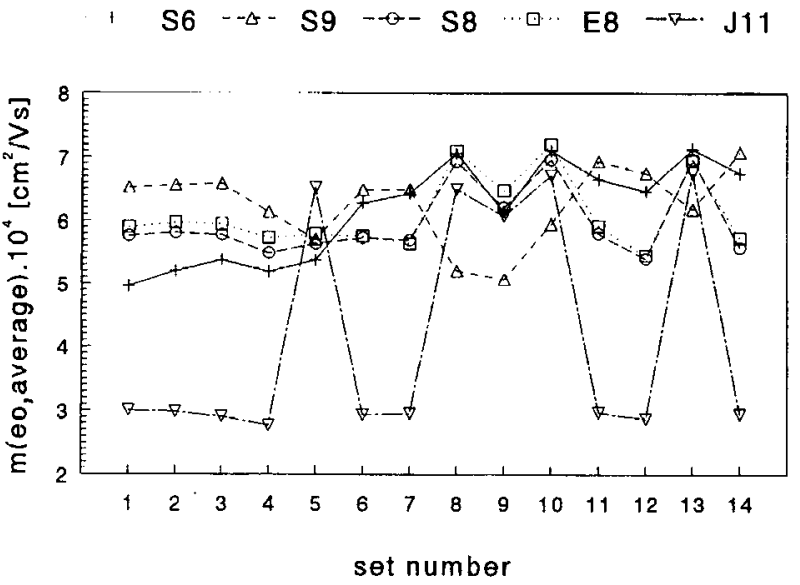

igure 7

The average values of the electroosmotic mobilities for individual sets of analyses with in a matrix of measurements performed on columns $56,59,58$ $E 8$, and $\mathbf{J 1 1}$. The buffers used in the individual sets of analyses are summarized in Table 10. Sets 1-3 were measured the first day, sets 4-11 the second day, and sets 12-14 the third day. the lowest for the PHOSAM* buffer (pH = 7.4), whereas the PHOS buffer $(\mathrm{pH}=6.8)$ also yielded an electroosmotic mobility lower than that obtained with the TRIS buffer. With the PHOSAM buffer $(\mathrm{pH}=$ 9.5) the electroosmotic mobility lies between those obtained using the TRIS and PHOS buffers.

Lukacs et al. [12] reported that a small change in the $\mathrm{pH}$ of a buffer solution within the $\mathrm{pH}$ interval 5 to 8 may strongly influence electroosmotic mobility in silica capillaries. It is obvious that differences in electroosmotic mobilities obtained using different buffers cannot be explained solely in terms of $\mathrm{pH}$ differences. The effect might possibly be explained on the basis of interactions between the buffer molecules and the silica surface [9,21-29,36]. Buffer molecules containing nitrogen atoms are positively charged in solutions of appropriate $\mathrm{pH}$ and can thus interact with the silica surface. Because these interactions modify not only the surface charge of the capillary wall but also the electrical double layer structure, they also affect the electroosmotic mobility. In addition, the points plotted for columns S8 and E8 (two different manufacturers) in Figure 7 are almost coincident.

It thus seems that the PHOSAM buffer can eliminate differences in the electroosmotic mobilities of columns from different manufacturers. Such observations were not made for the TRIS buffer with columns S1, C1, E1, and J1 (Figure 2) or for the PHOS buffer with columns S4 and C4 (Figure 4)

The lowest repeatability of electroosmotic mobility was observed for column S6 with PHOS buffer (Figure 8; cf. Figure 1 and Table 3). With the other buffers very similar repeatabilities of electroosmotic mobilities were obtained within the individual sets of analyses (Figure 8). When the PHOS buffer was employed after the use of the TRIS buffer in column $S 9$ in sets 8-10 and 13, the EOF repeatability again became poor. If, on the other hand, the PHOS buffer was applied after the use of the PHOSAM or PHOSAM* buffers in columns S8, E8, and J11 in sets 8-10 and 13, the EOF stability remained satisfactory. columns:
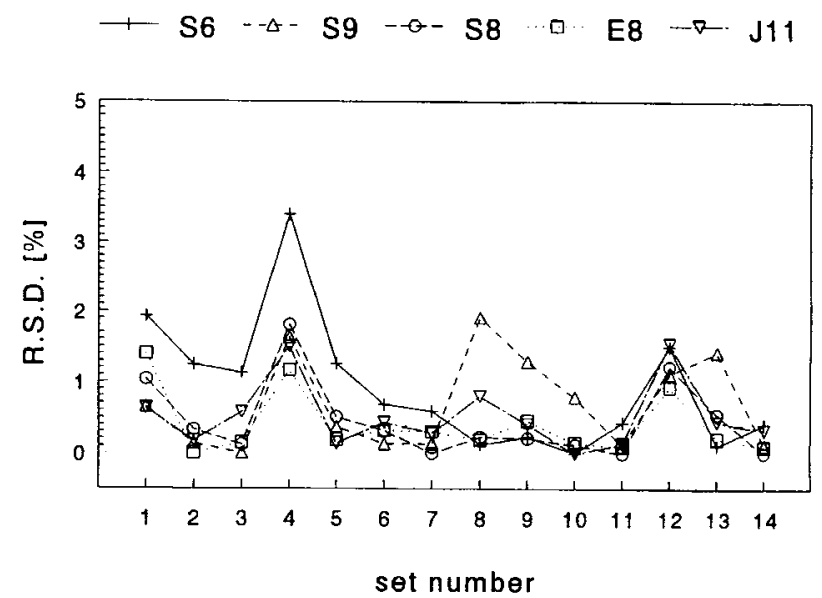

Figure 8

$R S D$ values of the electroosmotic mobilities for individual sets of analyses within a matrix of measurements performed on columns $\mathrm{S6}, \mathrm{S9}, \mathrm{S8}, \mathrm{E8}$, and J11. The buffers used in the individual sets of analyses are summarized in Table 10. Sets 1-3 were measured the first day, sets 4-11 the second day, and sets 12-14 the third day. 


\section{Table 10}

The buffers used in the individual sets of analyses with columns S6, S9, S8, E8, and J11.

\begin{tabular}{|c|c|c|c|c|c|}
\hline $\begin{array}{l}\text { Set } \\
\text { number }\end{array}$ & $\begin{array}{l}\text { Column: } \\
\text { S6 }\end{array}$ & S9 & S8 & E8 & J11 \\
\hline 1 & PHOS & TRIS & PHOSAM & PHOSAM & PHOSAM* \\
\hline 3 & PHOS & TRIS & PHOSAM & PHOSAM & PHOSAM $^{*}$ \\
\hline 4 & PHOS & TRIS & PHOSAM & PHOSAM & PHOSAM ${ }^{*}$ \\
\hline 5 & PHOS + SDS & TRIS + SDS & PHOSAM + SDS & PHOSAM + SDS & PHOSAM $^{*}+$ SDS \\
\hline 8 & TRIS & PHOS & PHOS & PHOS & PHOS \\
\hline 9 & TRIS + SDS & PHOS + SDS & PHOS + SDS & $\mathrm{PHOS}+\mathrm{SDS}$ & $\mathrm{PHOS}+\mathrm{SDS}$ \\
\hline 10 & TRIS & PHOS & PHOS & PHOS & PHOS \\
\hline 11 & PHOS & TRIS & PHOSAM & PHOSAM & PHOSAM ${ }^{\star}$ \\
\hline 12 & PHOS & TRIS & PHOSAM & PHOSAM & PHOSAM $^{*}$ \\
\hline 13 & TRIS & PHOS & PHOS & PHOS & PHOS \\
\hline
\end{tabular}

\subsection{The Influence of the Butfer Additives on EOF}

The influence of a number of additives, such as SDS, 1-butanol, and the sodium salts of 1-pentanesulfonic acid and 1-heptanesulfonic acid, on the magnitude and repeatability EOF was also investigated. These additives are often used to create micelles in the buffer, to improve its capacity to dissolve solutes, and/or to modify EOF. When PHOS or TRIS buffers contained SDS, the electroosmotic mobilities were ca $10 \%$ less than those obtained with the pure buffers. The electroosmotic mobilities of PHOS buffers containing 1-butanol or sodium salts of the sulfonic acids were, respectively, 5 and $20 \%$ below those of the pure PHOS buffers.

Many reports have already described the influence of buffer additives, e.g. poly(vinyl alcohol), lower alcohols, and SDS, on EOF $[10,14,20,30,33]$. Effects on electroosmotic mobility have often been attributed to changes in the viscosity of the buffer and/or the nature of the electrical double layer as a result of the presence of the additives. The relatively low concentrations of additives used in this study, i.e. $50 \mathrm{~mm}$, corresponding to ca $1 \% \mathrm{w} / \mathrm{w}$, do not, however, strongly influence buffer viscosity or dielectric constant. It was, moreover, observed that some of the additives investigated may alter the buffer $\mathrm{pH}$, and that ionic additives, such as SDS and the sodium salts of sulfonic acids, markedly changed the ionic strength of the buffer and thus also the thickness of the electrical double layer and the zeta potential. It is clear that even small changes in viscosity, dielectric constant, $\mathrm{pH}$, or ionic strength can have a significant effect on the electroosmotic mobility; this may satisfactorily explain the effects of buffer additives on EOF observed.

This is also supported by some of the results obtained in this investigation. 1-Butanol does not alter the $\mathrm{pH}$ and ionic strength of buffers and thus the drop in the electroosmotic mobility is small. Addition of SDS to the PHOSAM buffer had no influence on the electroosmotic mobility (Figure 7, columns S8 and E8, set 5). Both the $\mathrm{pH}$ and the ionic strength of the PHOSAM buffer is only slightly changed by the addition of SDS (in this buffer these two properties already have relatively high values). Finally, when the PHOSAM* buffer containing SDS (final $\mathrm{pH}=8.5$ ) was used with column J11 (Figure 7) the electroosmotic mobility increased to ca $132 \%$ of the value measured using pure PHOSAM* ${ }^{*}$ owing to the lower $\mathrm{pH}$ of the pure PHOSAM$^{*}$ buffer (7.4). The PHOSAM* and PHOSAM* + SDS buffers had different initial compositions (Table 1) and thus their final $\mathrm{pH}$ values were different; this prevented precipitation of SDS by ethylenediamine at low $\mathrm{pH}$.

The repeatability of electroosmotic mobility obtained by use of other buffer - additive combinations was not significantly different from that obtained by use of the pure buffer

\subsection{General Observations}

It is obvious from the data in Figures 1 and 6 that the electroosmotic mobility under different experimental conditions slowly varies until a stable EOF is established. Smith et al. [33] reported a similar observation: 'There is evidence that the surface of the capillary undergoes modification until a steady-state condition has been established. It may require several runs to reach this condition.' The day-to-day repeatability of the electroosmotic mobility was measured for column S5 with PHOS buffer after attainment of the steadystate condition (i.e. after ca 40 runs); satisfactory day-to-day repeatability of electroosmotic mobility $(1.1 \% R S D)$ was observed during a one week period provided the first sets of analyses every morning were not included in the calculation. There is evidence that it is neither the processes used in manufacture of the capillary nor the procedures used for pretreatment of the column, but rather the nature of the buffer, which has most influence in determining the number of runs required to attain this steady-state condition.

The repeatability and magnitude of the EOF decreased for all capillaries during a period of storage, i.e. overnight, over the weekend, etc. This is apparent from Figure 1 for sets 4 and 12, in Figure 3 for sets 7 and 15, in Figure 5 for sets 4 and 12, and in Figure 8 for sets 4 and 12 . The same phenomenon has already been observed by Schwer and Kenndler [4]. A possible explanation may be the formation of a porous gel layer at the silica - solution interface during the storage period; this leads to a lower EOF than that which results from a fresh silica surface [34]. From this study it was concluded that after each period of storage the EOF stability could be recovered by performing several runs or applying a high voltage for a short period of time. 


\section{Conclusion}

It can be concluded from the results obtained in this study that the nature of the running buffer plays the most significant role in determining the repeatability and magnitude of the electroosmotic mobility; the column manufacturing process and its pretreatment are less important.

The widely used PHOS buffers proved to be less suitable than TRIS or PHOSAM buffers in respect of the stability and repeatability of EOF. Buffers consisting of TRIS and ethylenediamine resulted in an EOF with better characteristics than those from pure PHOS buffers. Finally, the buffer additives investigated in this study altered only the magnitude of the electroosmotic mobilities, but not the repeatability.

\section{Acknowledgement}

This work was supported by a TEMPUS program under contract number JEP 037992/1.

\section{References}

(1) F.F. Reuss, Memoires de la Societé Imperiale de Naturalistes de Moscou 2 (1809) 327.

[2] H. Helmhoitz, Ann. 7 (1879) 337.

[3] K. Salomon, D.S. Burgi, and J.C. Heimer, J. Chromatogr. 559 (1991) 69-80.

(4) Ch. Schwer and E. Kenndler, Anal. Chem. 63 (1991) 1801-1807.

[5] A.A.A.M. van de Goor, B.J. Wanders, and F.M. Everaerts, J. Chromatogr. 470 (1989) 95-104.

[6] K. Stulik and V. Pacáková, Electroanalytical Measurements in Flowing Liquids, Ellis Horwood, Chichester, UK (1987) 22-24.

[7] M. von Smoluchowski, Bull. Int. Acad. Sci. Cracovie (1903) 184

[8] W.J. Lambert and D.L. Middleton, Anal. Chem. 62 (1990) 1585-1587.

[9] K.D. Altria and C.F. Simpson, Chromatographia 24 (1987) 527-532.

[10] S. Terabe, H. Utsumi, K. Otsuka, T. Ando, T. Inomata, S. Kuze, and Y. Hanaoka, J High Resoln Chromatogr. Chromatogr. Commun. 9 (1986) 666-670.

[11] J. Kohr and H. Engelhardt, J. Microcol. Sep. 3 (1991) 491-495

[12] K.D. Lukacs and J.W. Jorgenson, J. High Resoln Chromatogr. Chromatogr. Commun. 8 (1985) 407-411.
[13] M. Huang, W.P. Vorkink, and M.L. Lee, J. Microcol. Sep. 4 (1992) 135-143.

[14] B.B. van Orman, G.G. Liversidge, G.L. McIntire, T.M. Olefirowicz, and A.G. Ewing, J. Microcol. Sep. 2 (1990) 176-180.

[15] H.J. Issaq, I.Z. Atamna, C.J. Metral, and G.M. Muschik, J. Liq. Chromatogr. 13 (1990) 1247-1259.

[16] I.Z. Atamna, C.J. Metral, G.M. Muschik, and H.J. Issaq, J. Liq. Chromatogr. 13 (1990) 2517-2527.

[17] I.Z. Atamna, C.J. Metral, G.M. Muschils, and H.J. Issaq, J. Liq. Chromatogr. 13 (1990) 3201-3210.

[18] H.J. Issaq, I.Z. Atamna, G.M. Muschik, and G.M. Janini, Chromatographia 32 (1991) 155-161.

[19] S. Fujiwara and S. Honda, Anal. Chem. 59 (1987) 487-490.

[20] S. Terabe, K. Otsuka, and T. Ando, Anal. Chem. 57 (1985) 834-841

(21] J.A. Bullock and L. Ch. Yuan, J. Microcol. Sep. 3 (1991) 241-248.

(22) W. Nashabeh and Z.E. Rassi, J. Chromatogr. 514 (1990) 57-64.

[23] C.L. Ng, H.K. Lee, and S.F.Y. Li, J. Chromatogr. Sci. 30 (1992) 167-170.

[24] K.D. Altria and C.F. Simpson, Anal. Proc. 23 (1986) 453-454.

[25] A. Emmer, M. Jansson, and J. Roeraade, J. High Resoln Chromatogr. 14 (1991) $738-740$.

[26] W.G.H.M. Muijselaar, C.H.M.M. de Brujin, and F.M. Everaerts, J. Chromatogr. 605 (1992) $115-123$.

[27] T. Tsuda, J. High Resoln Chromatogr. Chromatogr. Commun. 10 (1987) 622-624.

[28] A. Emmer, M. Jansson, and J. Roeraade, J. Chromatogr. 547 (1991) 544-550.

[29] J.E. Wiktorowicz, US Patent 5015350, May 14, (1991).

[30] M. Gilges, H. Husmann, M.H. Kleemiß, S.R. Motsch, and G. Schomburg, J. High Resoln Chromatogr. 15 (1992) 452-457.

[31] J.T. Smith and Z.E. Rassi, J. High Resoln Chromatogr. 15 (1992) 573-578.

[32] Ch.S. Lee, D. MCManigill, Ch.T. Wu, and B. Patel, Anal. Chem. 63 (1991) 15191523.

[33] S.C. Smith, J.K. Strasters, and M.G. Khaledi, J. Chromatogr. 559 (1991) 57-68.

[34] T.-L. Huang, Chromatographia 35 (1993) 395-398

[35] X.-W. Yao, D. Wu, and F.E. Regnier, J. Chromatogr. 636 (1993) 21-29.

[36] H.-T. Chang and E.S. Yeung, Anal. Chem. 65 (1993) 650-652.

Ms received: January 24, 1994 Accepted: March 17, 1994 